\section{IJOSES \\ e-ISSN 2148-8673 \\ Uluslararası Sosyal ve Eğitim Bilimleri Dergisi \\ International Journal of Social and Educational Sciences \\ Cilt 5, Sayı 9, Haziran 2018 \& Vol 5, No 9, June 2018 (C)2018 Telif Hakkı IJOSES'e aittir}

DOI: $10.20860 /$ ijoses.417086

Geliş Tarihi \& Received: 19.04.2018 http://dergipark.gov.tr/ijoses

http://www.ijoses.com

Finlandiya, İngiltere ve Türkiye’nin Okul Öncesine Yönelik Sosyal Politika Uygulamaları*

Social Policy Implementations for the Early Years from Finland, England and Turkey

\title{
İlknur Şemşek**
}

\section{$\ddot{O} \mathbf{z}$}

Sosyal politika alanında yapılan reformlardan en fazla payı alanlardan biri de eğitim olmuştur. 19. yüzyıldan itibaren çocuk ve gençler gerek sosyal, gerekse ekonomik yönlerden dezavantajlı duruma düşmüşlerdir. Günümüzde sosyal politikanın alanı olarak kabul edilen çocuk bakımı ve eğitimi, zamanla devletlerin ilgisini çekmiş ve yapılan politikalarda okul öncesi yaşlar için yenilikler düzenlenmiştir. Bu çalışmanın amacı; okul öncesine yönelik sosyal politikalar ve uygulamalar arasındaki benzerlik ve farklılıkların ortaya konulması ve somut önerilerin geliştirilmesidir. Bu bağlamda Avrupa Birliği’ne üye olan İngiltere, Finlandiya ve üyelik için müzakerelere devam eden Türkiye örnekleri incelenmiştir.

Anahtar Kelimeler: Sosyal Politika, Okul Öncesi Eğitim, Türkiye, İngiltere, Finlandiya

\begin{abstract}
One of the largest part of social policy reforms have been made in educational field. Young people have become one of disadvantaged groups in terms of social and economic aspects since the 19th century. In today's world child care and education regarded as a field of social policy has attracted interest of the states over time and therefore new reforms for the early years have taken place in policies and procedures. The purpose of this study is to put similarities and differences of early years' social policies and their implementations forward and develop some concrete proposals. In this context, examples of England and Finland as members of the European Union and Turkey as a candiate member of the Union are examined.
\end{abstract}

Keywords: Social Policy, Early Years Education, Turkey, England, Finland

\footnotetext{
* Bu makale yazarın "Sosyal Politika Açısından Okul Öncesi Eğitime Yönelik Uygulamalar: İngiltere, Finlandiya ve Türkiye Örnekleri” başlıklı yüksek lisans tezinden üretilmiştir.

**ilknursemsek@gmail.com; ORCID: orcid.org/0000-0002-9098-0609
} 


\section{Extended Summary}

One of the largest part of social policy reforms have been made in educational field. Children and young people have become one of disadvantaged groups in terms of social and economic aspects since the 19th century. In today's world, child care and education regarded as a field of social policy has attracted interest of the states over time and therefore new reforms for the early years and youth have been made in the policies and procedures. The purpose of this study is to put similarities and differences of early years' social policies and their implementations forward and develop some concrete proposals. In this context, examples of England and Finland as members of the European Union and Turkey as a candiate member of the Union are examined.

The idea of education for the preschool age group has shown itself during child development studies. The work of 17 th and 18th century scholars on this subject is striking. The preschool education period covers the years from the birth of the child until the beginning of primary school. It is a period in which children develop their personal qualities. Preschool education, generally between the ages of 0 and 5, gets taken into social policies by current governments. Early years education comes before compulsory education and the child's family is also directly attached to the policies too. Early years care and education is vitally important, especially as women becoming more involved in the business of the globalizing world. Education and care policies are known as one of the most important issues in the field of social policy. Social change, which is seen visibly on the global scale, increases the importance of social policies towards education and care. When we look at the social policies of the liberal welfare state of England and the Nordic model of Finland, what emerges is the equal opportunities throughout their education system.

Preschool education is the first and most important stage of educational life. This stage plays an important role in the child's social and emotional development, which helps them to be more social, productive, resourceful and capable thinkers in their adulthood. Thus most countries like Finland, England and Turkey give importance to early years education. Preschool settings can be attached to primary schools or can be on a separate premise. The adoption of the "social state" principle, which forms the basis of social policies for education, seems to accelerate preschool education-oriented social policies. The sound and harmonious nature of education policies is vital to combat poverty.

Early years education is not compulsory in all three countries. Finland's, England's and Turkey's early years education show similarities in terms of structure. Preschool enrollment rate is lower in Turkey compared to other two countries. Both private and public schools opportunities can vary. This was not observed in schools of Finland and England. The sosyo-economic structure of the population varies in these countries. Early years policies are at the top of the governments agendas especially in England and Finland. Discourses are similar in all three state governments, emphasizing the importance of diversity, innovation, flexibility and choice in education at the stage of compulsory education.

It is noteworthy that Finland chooses its teachers among those who have post graduate degrees in the field of teacher training. Turkey has been working towards the same objectives with other countries too and giving extra attention to Turkish language being used correctly and effectively throughout pupils' educational life. Working in partnership with parents and carers especially in England and Finland were found more effective. The curriculum in Finland is more flexible and local than England and Turkey. Compulsory education age varies in all three countries. England, Finland and Turkey's national values, culture, language, traditions and history 
background are different than eachother, therefore it should be considered as normal when it comes to practices.

Financing the educational system and the methods are assessed in different categories in all three countries depending on their level of development. Local government resources get used more in England and Finland than Turkey. The proportion of families with higher incomes benefit from preschool education in Turkey is higher. Those who are under the poverty line should be provided with organized and widespread access to education and necessary assessments should be made. Particularly educational policies should be based on the equal opportunities. The study concluded that the services and policies provided for the preschool age group were not only related to the child, but also directly or indirectly involved the child's family too. This creates positive consequences for the socio-economic level of the family and provides opportunities for the mother, father or the carer to return to working life.

\section{Giriş}

19. yüzyıldan itibaren çocuk ve gençler gerek sosyal, gerekse ekonomik yönden dezavantajlı duruma düşmüşlerdir. Günümüzde sosyal politikanın alanı olarak kabul edilen çocuk bakımı ve eğitimi, zamanla devletlerin ilgisini çekmiş ve yapılan politikalarda okul öncesi yaşlar için yenilikler düzenlenmiştir. Sosyal politika alanında yapılan reformlardan en fazla pay alanlardan biri de eğitim olmuştur. Bu uğurda tarih boyunca eğitim merkezleri açılmış ve bireyler farklı alanlarda ilk, orta ve yüksek derecede eğitim almışlardır. Günümüzde hızla değişen ekonomik ve sosyal yapılar, eğitimi doğrudan etkilemekte, dolayısıyla eğitim sistemleri değişime uğramaktadır. Bir eğitim sisteminin oluşturulmasında göz önünde bulundurulan en önemli üç kriter; bir ülkenin iktisadi, toplumsal ve siyasi koşullarıdır.

Okul öncesi yaş grubuna yönelik eğitim fikrinin, çocuk gelişimi çalışmaları sırasında ortaya çıktığı görülmektedir. 17. ve 18. yüzyıl düşünürlerinin bu konudaki çalışmaları dikkat çekicidir. Genel ifadeyle okul öncesi eğitim, çocuğun doğumundan ilkokula başladığı döneme kadar olan yılları kapsamaktadır. Bu dönem çocukların kişisel özelliklerini geliştirdikleri bir dönemdir. Günümüz hükümetleri tarafından genel olarak 0 ile 5 yaş arasını kapsayan yaş grubunun sosyal politika alanı içerisine alındığı görülmektedir. Erken yaş eğitimi zorunlu eğitimden önce gelmektedir ve konu çocuk olunca yapılan politikalardan aile de doğrudan ilişiklendirilmektedir. Özellikle küreselleşen dünyanın iş hayatında kadınların daha çok rol almasıyla okul öncesi bakım ve eğitimi hayati önem kazanmıştır.

$\mathrm{Bu}$ çalışmanın amacı; İngiltere, Finlandiya ve Türkiye'de okul öncesine yönelik sosyal politikaları incelemektir. Okul öncesi eğitim ve bakımın, sosyal politika açısından değerlendirilmesiyle ilgili yapılan çalışmaların azlığından söz edilebilir. Okul öncesi eğitimin sosyal politika uygulamalarındaki yeri araştırılırken, Finlandiya ve Türkiye anayasaları ve İngiltere'nin kanun ve yönetmeliklerinde okul öncesi döneme ait eğitim, bakım ve çocuk haklarıyla alakalı sosyal politikalar incelenmiş ve çalışmaya dahil edilmiştir. Liberal refah devleti olan İngiltere'nin ve İskandinav refah modeli olan Finlandiya'nın eğitim ve bakıma yönelik sosyal politikalarına bakıldığında, genel manada eğitim sistemi ve eğitimde fırsat eşitliği karşımıza çıkmaktadır.

\section{Sosyal Politika, Eğitim ve Okul Öncesi Eğitim}

Sosyal politika günümüzde çeşitli biçimlerde tanımlanmaktadır. Doğru bir tanım yapabilmek için önce "sosyal" kelimesinin içeriğine bakılmalıdır. "Sosyal" kavramı, ilk olarak siyasal eşitlikle iktisadi eşitsizlik arasındaki durumu betimlemek maksadıyla 19. yüzyılda kullanılmıştır. 
Ardından "Sosyal Politika", devletin topluma yönelik aldığı kararlar ve uygulamaların bir bütünü olarak anlam kazanmıştır. Refah devleti faaliyetleri ile yakından ilgilenen sosyal politika, toplumun bireylerinin arasında ahengi temin etmek, tam istihdam sağlamak, çalışma şartlarını iyileştirmek, sosyal güvenlik sistemini adil bir şekilde düzenlemek, bölgeler arası dengesizlikleri ortadan kaldırmak maksadıyla yapılan uygulamalar ve alınan tedbirlerdir. Doğan'a göre sosyal politika "sağlık, eğitim, refah ve sosyal güvenlik hizmetleri gibi politika ve uygulamaları yürüten hizmetler toplamıdır” (Doğan, 2003, s.3). Günümüzde sosyal politikanın kapsamı farklılıklar göstermiş, toplumsal hayatı tehdit eden her türlü olumsuzluğa karşı mücadele başlatmış bir kimlik haline almıştır. Her bir sosyal politika türü bir sınıfsal ilişkiyi temsil etmektedir ve toplumsal düzendeki yeri çok önemlidir (Tokol \& Alper, 2013, s. 6). Sosyal Politika dar ve geniş anlamda ikiye ayrılmıştır. Sosyal Politika kavramı yalnızca devlet faaliyetlerini kapsıyorsa, dar anlamda bir sosyal politikadan söz edilebilir. Bu durumda toplumdaki sosyal ilişkiler ve çelişkiler karşısında devleti ve hukuksal düzeni ayakta tutmaya dönük çalışmalardır. Fakat zamanla sosyal politika dar kapsamlı içeriğinden sıyrılmış ve bugünkü geniş anlamlı yapısına dönüşmüştür (Doğan, 2003, s. 5). Dar anlamda sosyal politika, kapitalist düzen içinde emek ve sermaye sahipleri arasındaki adaletsizliği barışçı yollarla sona erdirmek, ekonomik ve toplumsal hayatın devamını sağlamaya yönelik politikalar olarak 19. yüzyılda belirmiştir. "Sosyal politikanın oluşumunda çalışma hayatında yaşanan değişim kadar, demografik alanda yaşanan değişimin de önemli etkisi bulunmaktadır. Sanayileşme sürecinde yaşanan hızlı kentleşme, sosyal politikanın gelişimine önemli etkide bulunmuştur"'(Tokol \& Alper, 2013, s. 4). Sosyal politika geniş anlamına, özellikle II. Dünya Savaşı'ndan itibaren kavuşmaya başlamıştır. "Klasikleşmiş sorunların yanısıra kapitalist bir toplum düzeni içindeki tüm toplumsal grupları" kapsamaktadır. Toplum politikası olarak geniş bir anlama hitap eden günümüz sosyal politikası, ortaya çıkan sosyal eşitsizliklerin tümünü içermektedir (Doğan, 2003, s. 5). Geniş anlamda sosyal politika, dar anlamdakinin aksine sadece işçi ve işveren sınıflarının sorunlarıyla değil, toplumun farklı kesimlerinin de sosyal düzeniyle ilgilenmektedir (Tokol \& Alper, 2013, s. 5).

Kavram olarak eğitimi tanımlamamız gerekirse; bireylerin bilgi, inanç, değer yargısı ve kültürel değerleri öğrenmesi ile hedeflenen noktaya ulaşılmak için faaliyete geçirilen uygulamalardır denilebilir (Çalışkan, 2007, s. 287). Aile, bireylerini kendi kültür kalıbına göre eğittiği gibi devlet de siyasal felsefesine göre yurttaşlarını eğitir. Günümüz neoliberalizm politikalarına orantılı olarak eğitim sistemlerinin de şekillendirilmesi yeni sorun alanları oluşturmaktadır. Zira ekonomik açıdan gelişmemiş ve gelişmekte olan ülkelerdeki yoksul insanlar küreselleşme sürecindeki eğitimden yeterince faydalanamamaktadırlar (Çınar, 2009, s. 16). Günümüzde kullanılan 'modern eğitim' kavramı aynı zamanda üretim ve verimlilik piyasalarına uyumu da içermektedir. Bu bağlamda eğitim sistemi ekonomik sistem ile paralel olarak gerekli insan tipini yapılandırmaktadır. Bilgi toplumu olan günümüz dünyasında rekabet artmış, buna ek olarak eğitim de önem kazanmıştır. Eğitimden elde edilen bilgi ve beceriler insana katma değer sağladığ1 gibi, yaşadığı topluma sosyo-ekonomik ve kültürel bağlamda da katkı sağlamaktadır. Dolayısıyla bu artılar ülke refahının gelişiminde olumlu etkiler yaratır. Eğitim ile refah düzeyi arasında bir doğru orantı mevcuttur. İstihdamı karşılanamayan birey gelir, eğitim, sağlık, güvenlik ve sosyal açıdan kendine yetemeyen biri olarak ortaya çıkmaktadır. Eğitim sosyal ve ekonomik anlamda eşitsizlikleri düzenleyici bir güce sahip olduğu kadar önlem alınmadığında bu olumsuzluğu artırıcı potansiyele de sahiptir. Ailenin geliri çocuğun okul hayatının nasıl olacağı konusunda etkin bir faktör belirlemekle birlikte ülkelerin finansman piyasalarına göre eğitim politikalarında da farklılıklar bulunmaktadır. Eğitim, örgün öğretimde devletin ideolojileri çerçevesinde müfredatlaştırıldığı için politiktir denilebilir. Bu özelliği ile tarafsız bir bilgi toplamı değildir (Çınar, 2009, 17). 
Çocuğun kişiliğini belirleyen özellikler okul öncesi dönemde kazanılmaktadır. Ayrıca bu dönem beden, zihin, hayal gücü, kas ve motor gelişimine katk1 sağlayan bir eğitim dönemidir (Akbıyık \& Kalkan, 2014, s. 3). Çocuk gelişim kuramcısı Erikson, erken çocukluk çağında edinilen tecrübelerin ilerleyen yaşın karakterini oluşturacağını savunmaktadır (Mooney, 2000, s. 38). Piaget, çocukların gelişimlerine katkıda bulunacak olan ilgi çekmek, sorunları kendi başlarına çözmek, öğrenmeleri için meraklandırmak gibi uygulamalar için gereken ortamın hazırlanması gerektiğini belirtmiştir. Diğer bir kuramcı Vygotsky, çalışmalarında çocukların birbirlerinden daha çok öğrendiklerini, özellikle dil gelişiminin bu sayede daha etkin olduğunu ve öğrenme aşamasında olan bir çocuğun bir öğretmenden veya bir sınıf arkadaşından yararlanabileceğini vurgulamıştır (Mooney, 2000, s. 83).

Okul öncesi eğitim; "çocuğun doğduğu günden temel eğitime başladiğl güne kadar geçen sifir-altı yaş arasındaki dönemi kapsayan ve çocukların daha sonraki yaşamlarında çok önemli bir yeri olan; bedensel, psikomotor, sosyal-duygusal, zihinsel ve dil gelişimlerinin büyük ölçüde tamamlandı̆̆, bu doğrultuda kişiliğin şekillendiği "Erken Çocukluk Çă̆ı" diye de adlandırılan gelişim ve eğitim süreci” dir (Çocuk ve Gelişim, 2008). Bu eğitim ailede ve kurumlarda verilmektedir. Kurumlardaki eğitimin daha planlı, yaş ve gelişim özelliklerini destekleyici şekilde verildiği görülmektedir. Yapılan etkinliklerde özellikle paylaşma ve yardımlaşma gibi sosyal beceriler edinmektedirler. Dil becerisini geliştirmeye yardımc1 olan okul öncesi eğitim, iyi hazırlanmış eğitim programları aracılığıyla çocuğun çevreye uyumunu kolaylaştırmaktadır. 17. yy'da Pestalozzi'nin, 18. yy'da Froebel'in 19. yy'da Montessori'nin yaptığ1 çocuk gelişimi ile ilgili çalışmalar bu alanın bilinen ilk bilimsel kayıtlarıdır. Okul öncesi eğitimin amaçları arasında; beden, zihin ve duygu gelişimini sağlamak, ilköğretime hazırlanmak, şartları uygun olmayan ailelerin çocuklarına eşit ortamda yetiştirilme imkânı sağlamak ve dil bilgisini geliştirmek vardır. $\mathrm{Bu}$ eğitim sürecinde; bireysel ihtiyaçlara ve farklılıklara uygun olunmalı, çocuk ilköğretime hazır duruma getirilmeli, eğitim ortamı eşit şartlara göre hazırlanmalı, deneyerek öğrenmeye firsat verilmeli, verilen eğitim sevgi, saygı, işbirliği, sorumluluk gibi davranışların geliştirilmesi yönünde olmalı, çocuğa öz denetim kazandırmalı, tüm etkinlikler oyun içermeli, baskı ve kısıtlama uygulanmamalı ve ailenin eğitim sürecine etkin katılımı sağlanmalıdır (Çocuk ve Gelișim, 2008).

\section{2. İngiltere, Finlandiya ve Türkiye'de Sosyal Politika ve Okul Öncesi}

İngiltere'de buhar makinesinin icadıyla birlikte ortaya çıkan yeni sosyo-ekonomik sorunlar çok geçmeden emeğin korunması gerekliliğini hissettirmiştir. "Çocuk, kadın, yaşlı ayrımı yapılmaksızın her gruptan insanın çok ucuz ücretlerle, çoğu zaman karın tokluğuna çalıştırılması, sanayileşme sürecinde alışıla gelmiş bir durumu oluşturmaktadır”' (Tokol \& Alper, 2013, s. 16). 1834'te alınan bir karara göre; yoksullar için 'yoksullar evi' diye belirlenen yerlerde yaşama yükümlülüğü getirilmiştir. Fiziksel olarak sağlıklı olan kişilerin, bölgelerinde bulunan kiliselerin uygun bulduğu işlerde görevlendirilerek yaşamlarını sağlamaları öngörülüyordu. $\mathrm{Bu}$ istihdamın giderleri kiliseye aitti ve kilisenin bölgede vergi toplama yetkisi vardı. Ayrıca kilisenin, gücü ve kuvveti yerinde olan fakirlerin çalıştırılmasının yanı sıra, yoksullar evi bulundurma, öksüz ve bakıma muhtaç çocukların çıraklık eğitimi, yaşlılar ve sakatların bakımı ve muhtaçların cenazelerini kaldırmak gibi görevleri de vardı. Akrabaları tarafından bakılmayan yoksulların çevre ve toplum tarafından bakılmasını ön gören 1601 Yoksullar Yasası, 1843'te yürürlükten kaldırılmıştır (Fraser, 2009, s. 40). İngiltere, Sosyal Refah Devlet politikalarının Almanya'dan sonra gelişmeye başladığı ülke olmuştur (Özdemir, 2007, s. 192). 19. yy'da burjuvazinin zenginleşmesi ve güçlenmesi ile diğer tarafta sıkıntılı bir işçi sınıfı ortaya çıkmıştır. Artık yoksulluk, üzerinde durulması gereken ciddi bir mesele olmuştur. 1950'li yı1lara gelindiğinde geçmiş dönemde bırakılan sosyal hayata, klasik refah devleti denilecek ve yeni devrin başladığ 1 kabul görecektir. İngiltere sosyal politika sisteminde Liberal Refah Modeli kullanmaktadır. 2008 
ekonomik krizinden son derece ağır bir şekilde etkilenen İngiltere'de, başta kamu olmak üzere birçok iş̧̧inin işine son verilmiş ve birçok iş yeri de kapatılmıştır. Kamunun sağladığı desteklerde hala kesintiler sürmektedir. 2014 verilerine göre kişi başına düşen gayri safi milli hasıla; 37955 Amerikan doları ve işsizlik oranı; \% 6,6'dır. İngiliz refah rejimi, piyasa temelli araçlar, özel sektör ve finans ağırlıklı bir biçimdedir ve emek kesimi açısından eşitsizlik yaratmaktadır (Özdemir, 2007, s. 193).

Bağımsızlı̆̆ını I. Dünya Savaşı'ndan sonra ilân eden Finlandiya'da aslında, aile sosyal politikası alanında alınan kararlar daha eskiye dayanmaktadır. İlk çocuk danışma merkezi 1904 yılında ve evli olmayan anneler için destek birimleri 1907 'de açılmıştır. İlkokullarda sağlık yasası 1920 'de, ilk çocuk kliniği 1922'de ve 1938 'de benzerlerinden daha farklı bir annelik yasası oluşturulmuştur. Günümüze kadar çocuk bakım ve eğitim hakları konusunda birçok kanun çıkartan Fin hükümeti, aynı zamanda dünyada ilk ücretsiz okul yemekleri sistemini de getiren ülke olmuştur. 1970 yılında engelli çocuklar için ödenek belirlenmiş, 2001 yılında 6 yaşın altındaki çocuklar için belediyeler tarafından eğitim ve bakımın ücretsiz karşılanması konusunda kararlar alınmıştır (Finlandiya Çocuk ve Aile Politikası, 2013, s. 9). Finlandiya, sosyal politikasında İskandinav (Nordik) modeli kullanmaktadır. "Sosyal faydaların herkes için aynı olduğu İskandinav modeli, Nordik model, Sosyal Demokrat model ya da Kurumsal model olarak da ifade edilir" (Şenkal \& Sariipek, 2007, s. 156). Bu modelin en önemli özelliği sosyal hizmettir. Güçlü birey yaratmada önemli bir yere sahip olan bu model, kamu sektöründe kadın istihdamı ve çocuk yetiştirme çabalarını kolaylaştırmış ve kadının emek piyasasındaki rolünü arttırmıştır. Bu durum devletin sosyal hizmetlerde daha fazla gelişiminin sağlamış ve neticede toplumda ayrımcılık karşıtı bir yapı oluşmuştur. Uluslararası alanda en çok ilgi gören politika sistemlerinden birisi olan İskandinav modeli takip eden Finlandiya, ilk olarak 1990 yılında meydana gelen ekonomik krizlerden dolayı bütçesinde kesintiler yapmıştır. Son yıllarda yaşanan 2008 ekonomik krizinden de etkilenen Finlandiya Devleti'nin sosyal hizmet alanındaki kesintileri devam etmektedir. Tüm krizlere rağmen devletin politikası, koşulları ne olursa olsun tüm vatandaşlara çalışma ya da aile durumuna bakılmaksızın yardım yapmak olmuştur. Sistem herkesi kapsar, geneldir ve yardımlar bireylere verilir (Şenkal \& Sariipek, 2007, s. 157). 2014 verilerine göre kiși başına düșen gayri safi milli hasılası 37.676 Amerikan doları ve işsizlik oranı \% 9'dur (Trading Economics).

Türkiye'de sosyal politika gelişimi Batı Avrupa'ya nazaran daha yavaş bir seyir göstermiştir. Eğitimin ücretsiz sunumu sağlanırken, sağlık alanı büyük oranda sigorta sistemlerine bağlantılı olarak yürütülmüştür. Diğer tarafta konut ve barınmaya müdahale Türkiye'de sınırlı bir şekilde gelişmiştir. Eğitimin haricinde sosyal politika alanında Batılı örneklere en yakın olarak sosyal sigortalar sisteminin oluşumunu görmekteyiz (Taştan, 2007, s. 64). Türkiye'de sosyal politikanın başlıca cumhuriyet öncesi ve cumhuriyet sonrası dönemler olmak üzere ikiye ayrıldığı görülmektedir. Cumhuriyet'le birlikte sosyal politika alanında genel bir düzenlemeye gidilmiştir. Önceleri maden işçilerini korumaya yönelik, daha sonraları Umumi Hıfzısıhha Kanunu ile kadın ve çocukların çalışma koşullarına ve sağlığına yönelik düzenlemeler getirilmiştir. 1923 yılında İzmir İktisat Kongresi'nde benimsenen kararlar doğrultusunda sanayileşmede liberal politikalar izlenmiş, 1930'lardan 1960'lara kadar daha çok zorunlu devletcilik uygulamaları görülmüştür (Tokol \& Alper, 2013, s. 64). Kamunun doğrudan doğruya işveren konumuna geldiği bu döneme örnek olarak İş Kanunu'nu verebiliriz. İş Kazaları, Meslek Hastalıkları ve Analık Sigortaları Kanunu, İşçi Sigortaları Kurumu Kanunu, İhtiyarlık Sigortası, Yaşlılık, Maluliyet, Ölüm Sigortası ve T.C. Emekli Sandığı Kanunu gibi yasal düzenlemeler çoğunlukla 2. Dünya Savaşı'ndan sonra gerçekleştirilmiş̧tir (Doğan, 2003, s. 112). 1980'ler ve 1990'lardan sonra dünyanın gündemine oturan yoksulluk olgusu birçok ülkeyi etkilediği gibi Türkiye'de de yankılar uyandırmıştır. Dünya Bankası ve Birleşmiş Millletler yeni bir sosyal politika olgusu yaratmış, bir çok kanun ve tüzük 
bu anlayış çerçevesinde değişime uğramıştır (Atılgan \& Çakar, 2007, s. 70). “1980’lerden 2000'li yıllara uzanan dönemde eğitim gibi önemli sosyal niteliğe sahip olan bir alana ayrılan bütçe azaltılmıştır" (Doğan, 2003, s. 113). Yeni sosyal politikayi benimseyen Türkiye 1990'lardan itibaren bir yenilenme içerisindedir ve diğer sosyal güvenlik kurumlarının da finansmanına fiili olarak katılmaktadır. Türkiye, 1999 yılı itibariyle AB müzakerelerine ağırlık vermiş, özellikle 2005 yılı itibariyle sosyal politikalarında Avrupa'ya uyumlu bir şekilde hareket etmiştir. 2006 yılında Sosyal Sigortalar Kurumu, Emekli Sandığı, ve Bağ-Kur bir çatı altında, Sosyal Güvenlik Kurumu şeklinde toplanmıştır. Güney Avrupa Refah Rejimi'ne benzetilen Türkiye sisteminde, sosyal yardım ve hizmet alanının gelişim içerisinde olduğu görülmektedir. 2014 verilerine göre kişi başına düşen gayri safi milli hasılası 8716 Amerikan doları ve işsizlik oranı \% 9.7'dir (Trading Economics).

\section{1.İngiltere'de Okul Öncesi Ĕ̆itim ve Öğretim}

Zorunlu eğitimden önce gelmekle birlikte beş yaşın altındaki çocukların katıldığı eğitimdir. Okul öncesi eğitim uygulamaları yerel otoriteler, bağımsız ya da gönüllü kuruluşlar tarafindan yürütülmektedir ve zorunlu değildir (Çetinkaya, 2005, s. 82). Zorunlu eğitim öncesi, 3 ile 5 yaş arasındaki çocuklar için devletin finanse ettiği bu okullar İngiltere'de temel eğitim düzeyini oluşturmaktadır ve kişisel, toplumsal, duygusal gelişim, iletişim, dil, okuryazarlık, matematik gelişimi, fiziksel gelişim ve hayal gücünün geliştirilmesi amaçlanmaktadır (Kilimci, 2013, s. 8). Kanunda, okul öncesi kurumlarının öğrenci ve öğretmen mevcudu şu şekilde belirlenmiştir; 1 yaşın altındakiler ve 1 yaşındakiler için 3 çocuğa 1 öğretmen, 2 yaştan 3 yaşa kadar 4 çocuğa 1 öğretmen, 3 yaşından büyükler için 13 çocuğa 1 öğretmen tanınmakta (İngiltere Eğitim Bakanlığı, 2013, s. 8), ve genelde öğretmenlerin yanında bir de yardımcı öğretmen bulunmaktadır. Yardımc1 öğretmen vasfinda çalışanların yeni yönetmeliklere göre en az Üçüncü Seviye (Level 3) diplomasına sahip olmaları gerekmektedir. Her okul öncesi sınıfı, özel eğitime ihtiyacı olan öğrenciler için de bir kaynaştırma sınıfi görevini görmekte ve eğer sınıfta özel eğitime ihtiyacı olduğu raporla belirlenmiş bir çocuk varsa ayrıca birebir öğretmen tahsis edilmektedir. 2013 verilerine göre İngiltere'de, okul öncesi eğitim ve bakım görevini üstlenen yaklaşık 121,300 adet merkez mevcuttur. Bu merkezler arasında tam gün ve yarım gün hizmet verenler $(25,000)$, kahvaltı grupları $(12,800)$, okul sonrası grupları $(13,400)$, tatil kulüpleri $(7,200)$, evinde ruhsatlı çocuk bakım hizmeti verenler (childminders) $(46,100)$, bağımsız anaokulları (400) ve okullara bağlı anaokulları ve hazırlık sınıfları $(16,400)$ bulunmaktadır (Department for Education, 2014, s. 34). İngiltere Eğitim Bakanlığı tarafından yapılan 2013 araştırma verilerine göre okul öncesi yaş grubu çocuk sayısı yaklaşık olarak 4,000,000'dur. Hemen hemen her çocuk herhangi bir okul öncesi eğitim ve bakım kurumundan yararlanmaktadır. Okul öncesi kurumlarından yararlananların sayısı 2011 ve 2013 yılları arasında \% 10'luk bir artış göstermiştir (Department for Education, 2014, s. 31). Okul öncesi eğitime katılan engelli öğrenci sayısı 10,945'dir. Okul öncesi eğitime yönelik toplamda 20,065 adet özel eğitim veren kurum bulunmaktadır. 4 yaşın altı toplam öğrenci sayıs1 938,475 ve bu rakamın raporlu ve raporsuz olarak 84,090'nı özel eğitim öğrencisidir. Yerel eğitim otoritelerinin tahsis edeceği bütçe, merkezi otorite tarafından onaylanmaktadır. İngiltere'de eğitimin finansman kaynağı, yerel yönetimler, özel kuruluşlar ve okul yönetimleridir. Özellikle yerel kaynakların önemi çok büyüktür (Gülay \& Ekici, 2010, s. 64). 1980'li yıllardan itibaren başlayan özelleştirme politikalarıyla birlikte, eğitim politikaları da etkilenmiş, okullar yarı özerk duruma getirilmiş ve eğitim standartları merkezileştirilmiştir (Süngü, 2005, s. 1). Kamu kurumu olan üniversite ve politeknikleri ${ }^{1 *}$ finansmanı Yükseköğrenim Fonlama Konseyi (The Higher Education Funding Council for England-HEFCE) tarafindan yürütülmektedir. Aynı zamanda finansal açıdan devlete bağlıdırlar ve bağımsız bir yönetime

\footnotetext{
* Türlü teknik bilgilerin ve üretime dayalı uygulamalı derslerin öğretimine ağırlık tanıyan üniversite, bkz. http://politeknik-nedir.cix1.info/, Erişim 24.5.2015.
} 
sahiptirler. "Araştırma Konseyi (the Research Council) kamu fonlarını bilimsel ve teknik araştırmalar için üniversite ve kolejlere dağıtırken, öte yandan HEFCE, üniversitelerin araştırma kapasiteleri, bunların idame ettirilmesi ve enstitüler arasındaki ilişkiyi sağlar" (Çiçekçisoy, 2013, s. 1). 2013/2014 yll rakamlarına göre Ingiltere hükümetinin genel olarak eğitime harcadiğl miktar 42 milyon Sterlin olmakla birlikte bu rakamın 30 milyon Sterlin'i okullara dağıtılmıştır ve okul öncesi yaş grubu için harcanan meblağ yaklaşık olarak 9 milyon Sterlin'dir (Department for Education, 2014).

\subsection{Finlandiya'da Okul Öncesi Eğitim ve Öğretim}

Eğitimin tamamen ücretsiz olduğu Finlandiya'da okul öncesi eğitimden lise eğitimi sonuna kadar öğle yemeği de ücretsiz olarak verilmektedir. 1 öğretim y1lında 190 günlük eğitimin verildiği Finlandiya'da yaz tatili 2,5 aydır. Eğitim, güz ve bahar dönemi olarak ikiye ayrılmaktadır. Esnek bir müfredata sahip olan Fin eğitim sisteminde öğretmenler, genel kabul görmüş ilkelere ters düşmemek kaydıyla yöntem ve teçhizat kullanımında serbesttirler. Ayrıca öğretmenlerin teftişi yapılmamaktadır. Finlandiya'da anaokulları, "Sağlık ve Sosyal İşler Yardım Bakanlığı" nın yasa ve yönetmeliğiyle yönetilirler. 7 yaşından küçük çocukların, ailelerinin isteği doğrultusunda bir anaokuluna kayıtları yaptırılabilir. Maddi durumu yeterli olmayan ailelere gereken destek belediyeler tarafından yapılmaktadır. Zorunlu olmayan okul öncesi eğitimin standartları, Ulusal Eğitim Kurulu tarafından belirlenmiștir. Okul öncesi öğretmenleri üniversite veya teknik okul gibi yükseköğretim okullarından mezun olmak zorundadırlar. Yardımc1 öğretmenler lise mezunu olabilmektedir. Okul öncesi eğitimde başlıca öğretilenler; dil ve etkileşim, matematik, ahlak ve felsefe, doğa ve çevre, sağlık, fiziki ve motor kas gelişimi ile kültür ve sanat dersleridir (Özer Çetinkaya, 2014, s. 11). Okul öncesi sınıflarında bir öğretmen kaç çocuğa bakabilir konusunda herhangi bir ulusal sınırlama getirilmemiştir. Finlandiya'da okul öncesi eğitimin amaçları; "çocukların kişiliğini tanımak, çocukları aktif bir bilgi alıcısı ve ögrenicisi olarak görmek, çocukların toplumun bir bireyi olarak yetiştirilmelerini ve doğal çevreye uyumlarını sağlamak, oyun ve ĕgitim ortamı yaratarak değişik etkinlikler ile çocukların diğer çocuklar ile birlikte kişiliklerinin gelişimini sağlamak, ailelere çocuklarını yetiştirmede yardımcı olmak, çocukların dengeli gelişimlerini sağlamaktır” (Usta, 2014, s. 18). 2013-2014 verilerine göre Finlandiya'da 7 yaşından küçük 425,000 çocuk bulunmaktadır ve 120,760 çocuk okul öncesi kurumlardan yararlanmıştır (Official Statistics of Finland, 2015). Okullara bağlı okul öncesi sınıfları haricinde yaklaşık 2,700 adet gündüz bakım evi bulunmaktadır. Gündüz bakım evlerine giden çocukların 40,000 kadarı bu evlere yarı zamanlı olarak katılmaktadır (Heinamaki, 2008, s. 7). 2014 yılı sonlarında yapılan kayıtlara ve istatistiklere göre Finlandiya'da okul öncesine hizmet edenlerin haricinde yaklaşı olarak 3,600 adet eğitim kurumu olduğu ve bu kurumlara katılan 1,89 milyon öğrenci olduğu belirlenmiştir. Bu öğrencilerden 157,000'i özel eğitim kapsamında yardım almıştır (Official Statistics of Finland, 2015). Finlandiya'da eğitim ücretsiz olmakla birlikte, eğitim kurumları devletten ödenek alırlar. Hükümetin, genel eğitime, mesleki ve sanat eğitimine para aktarma zorunluluğu vardır. Finansal yapı maliye bakanlığı ile eğitim bakanlığının ortaklaşa çalışması ile oluşturulmaktadır ve eğitimin finansmanı eğitim bakanlığı ve yerel yönetimler tarafından karşılanmaktadır (Güngör \& Göksu, 2013, s. 63). Öğrencilerin sosyo-ekonomik durumlarına göre yemek ve ders araç-gereçleri ücretsizdir. Eğitimin genel ilkeleri özel okullarda da uygulanmakla birlikte, özel okullar da para yardımından yararlanmaktadırlar (Özer Çetinkaya, 2014, s. 90). Eğitim kurumlarının ekonomik yönden desteklenmesi merkezi otoritenin yanı sıra yerel yönetimler tarafından da yapilır. "Illk ve ortaöğretim için kullanılan fonlarda devlet, masrafların \% 57'sini karşılarken, belediyelerin sağladı̆̆ katkı ortalama \% 43 civarındadır" (Ekinci \& Öter, 2010, s. 21). Yükseköğretim kurumlarının finansmanı ise doğrudan devlet tarafindan yapılmaktadır. 2013 rakamlarına göre 
Finlandiya'da eğitime 12,3 milyon Euro harcanmıştır (Official Statistics of Finland, 2015). Bu rakamın yaklaşık 3 milyon Euro’su okul öncesi eğitim için kullanılmıştır (OECD, 2013).

\subsection{Türkiye'de Okul Öncesi Eğitim ve Öğretim}

Türkiye'de okul öncesi eğitim zorunlu değildir. 3 ile 5 yaş arası eğitimi kapsar. Okul öncesi eğitimde amaç, çocukların bedensel, zihinsel, duygusal gelişimini ve iyi alışkanlıklar kazanmasını, onların ilk eğitime hazırlanmasını, koşulları elverişsiz çevrelerden gelen çocuklar için ortak bir yetiştirilme ortamı yaratılmasını, Türkçe'nin doğru ve güzel konuşulmasını sağlamaktır (Kilimci, 2006, s. 76). Okul öncesi eğitim yerleri özel işletmeler olabileceği gibi ilkeğitime bağlı olarak ta açılabilmektedir. Avrupa ülkeriyle karşılaştırıldığında Türkiye'de çocukların okul öncesi eğitime katılma oranının çok daha düşük olduğu görülmektedir. Buna sebep olarak okul öncesi eğitimin aileler için ek bir mali gider olmasını gösterebiliriz. 2014/15 Milli Eğitim istatistiklerine göre, Türkiye'de okul öncesi yaş grubuna hizmet veren toplamda 26,972 adet kurum bulunmaktadır. Bu kurumların 22,600'ü resmi, 4,372'si özeldir. Anaokulu, yaz okulu, mobil okul, Çocuk Hizmetleri Genel Müdürlüğü'ne bağlı okullar gibi çeşitlilikte karşımıza çıkmaktadır. Okul öncesi eğitime katılan toplam öğrenci sayısı 1,156,000 ve öğretmen say1s1 68,038'dir. 2014/15 Milli Eğitim Bakanlığ 1 istatistiklerine göre Türkiye'de 8,291 adet özel eğitim veren kurum, 823,515 adet özel eğitim alan öğrenci ve 93,042 tane özel eğitim veren öğretmen bulunmaktadır. Bu kurumlardan 4,372'si okul öncesi özel eğitim sunmakta olup, 171,648 okul öncesi özel eğitim alan çocuk ve 16,719 adet okul öncesi özel eğitim öğretmeni bulunmaktadır (Milli Eğitim Bakanlığı, 2015, s. 37). Türkiye eğitim sisteminin finansal yapısı merkezi bir özellik göstermektedir. "Okullar sınırlı özerkliğe sahiptirler ve ihtiyaçlarına cevap verebilme kapasiteleri sinırl düzeydedir” (OECD, 2013). Türkiye'de eğitimin finansman kaynakları; Eğitim Bakanlığı, Yükseköğretim Kurulu (YÖK), Katkı Payı ve Bağışlar tarafından karşılanmaktadır (Güngör \& Göksu, 2013, s. 63). Milli Eğitim Bakanlığı (MEB)'nın finansman kaynakları aşağıdaki gibidir;

- Konsolide bütçeden* ayrılan kaynaklar,

- İl özel idareden ayrılan kaynaklar,

- Eğitim, gençlik, spor ve sağlık hizmetleri vergisi,

- Eğitime katkı payı,

- Döner sermaye işletmelerinden sağlanan gelirler,

- Kişi ve kuruluşların bağışları (Çetinkaya, 2005, s. 110).

Eğitimin finansmanı kamu kaynaklarından sağlanmaktadır fakat okul aile birlikleri ve velilerde okulları mali yönden destekleyebilmektedirler. Okulların personel ihtiyacı merkezi ve yerel idareler tarafindan karşılanır. "Her ne kadar son on yıl içinde genel finansman düzeyi artmışsa da, mevcut veriler ilk ve ortaögretim finansmanının diğer OECD ülkelerine kıyasla yetersiz olduğuna işaret etmektedir" (OECD, 2013, s. 4). Eğitime ayrılan bütçe rakamlarına bakıldığında Milli Eğitim'e ayrılan bütçede artış olduğu gözlenmektedir. 2002 yılında 7,5 milyar olan eğitim bütçesi 2014 yılında 55 milyar TL'ye çıkarılmıştır. Okul öncesi eğitimde öğrenci başına yapılan yıllık harcama 2011 verilerine göre 2,400 Amerikan dolarıdır. Toplam öğrenci rakamına bakıldığında okul öncesi eğitime ayrılan miktar yaklaşık olarak 7 milyar TL olarak karşımıza çıkmaktadır (Ayrangöl ve Tekdere, 2014, s. 23).

*Türkiye'de konsolide bütçe, genel bütçe ve katma bütçelerin toplamından oluşur, bkz. http://konsolidebutce.nedir.com/ 


\section{Okul Öncesine Yönelik Sosyal Politika Örnekleri}

İngiltere hükümetinin anayasası bulunmamakla birlikte, haklar ve eşitlikler; yasalar ve tüzüklerle belirlenmiştir. Okul öncesi bakım ve eğitimi için devletin anaokullarına başlanması durumunda eğitim ücretsizdir. Özel anaokulu tercih edilirse, devlet 3 ve 4 yaşındaki çocukların haftada 15 saatlik eğitimini karşılamaktadır. Eğer ailenin maddi durumu iyi değilse ve devletten herhangi bir yardım alıyorsa 2 yaşındakiler de bu kapsama dahil edilmektedir (İngiltere Devleti İnternet Sayfası, 2014). Devlet okulları için adres uygulaması yapılmaktadır. Bu uygulamaya göre ikâmet edilen adrese yakın bir okula kayıt yapılabilmektedir.

Finlandiya, 1999 Anayasa'sında her vatandaşının eşit haklara sahip olduğunu, hiç kimseye cinsiyetinden, yaşından, uyruğundan, dilinden, dininden, sabıkasından, görüşlerinden, sağlığından, engelliliğinden ya $\mathrm{da}$ herhangi başka bir nedenden dolayı ayrımcılık yapılamayacağını belirtmiştir. Çocukların eşit hak ve imkanlardan yararlandırılması gerektiği, gelişimleri için gerekenin yapılması ve ücretsiz eğitimden yararlanmanın herkesin hakkı olduğu devlet ilkesi olarak kabul edilmiştir. Özel eğitime ihtiyacı olan çocukların diğer öğrencilerle aynı öğretim imkanlarına sahip olabilmeleri kanunen güvence altına alınmıştır (Finlandiya Anayasası). Finlandiya'da okul öncesi dönem 0-7 yaş arasıdır. İlköğretime başlamadan evvel çocuklar kreşlere ya da özel yuvalara gidebilmektedirler. 2001 yılından itibaren 6 yaşına gelen çocukların ücretsiz okul öncesi eğitimi almaları sağlanmaktadır. Okul öncesi eğitim yerel idareye bağlı olan okullarda, yuvalarda, kreşlerde ya da gündüz bakıma ilişkin aile kreşlerinde verilir. Zorunlu değildir, fakat 6 yaşındaki çocuklar okullara bağlı bölümlerde okul öncesi eğitim alabilirler. Katılım \% 98 oranındadır (Ekinci \& Öter, 2010, s. 12). Finlandiya aile politikasında çalışma hayatı ile aile hayatının uyumlaştırılması ilke edinilmiştir. 7 yaşın altındaki çocukların okul öncesi belediye kurumlarından yararlanma hakları vardır ve 6 yaşındakiler için ücretsizdir. Okul öncesi eğitimi maddi olarak karşılayamayanlar için destek sağlanmaktadır. Bütün bu olanaklara rağmen 6 yaşın altındaki okul öncesi kurumlarından yararlanma oranı düşüktür. 2013 verilerine göre; 3 yaşın altındakilerin \% 22'si tam zamanlı merkezlerde, \% 7'si yarı zamanlılarda bakım görmüşlerdir (European Agency, 2015).

Türkiye Cumhuriyeti Anayasası'na göre, her çocuk, korunma ve bakımdan yararlanma hakkına sahiptir. Devlet bu doğrultuda her türlü tedbiri almakla yükümlüdür. Kimse eğitim ve öğretim hakkından yoksun bırakılamaz. Öğrenim hakkının kapsamı kanunla tespit edilir ve düzenlenir. Devlet, maddi imkanlardan yoksun öğrencilerin, öğrenimlerini sürdürebilmeleri amaci ile gerekli yardımları yapar (Türkiye Cumhuriyeti Anayasas1, 1982). Türkiye'de resmi ve özel kuruluşlar tarafından açılan okul öncesi eğitim kurumları, Milli Eğitim Bakanlığı ve Aile ve Sosyal Politikalar Bakanlığı tarafından denetlenmektedir. Son yıllarda yapılan değişikliklere göre okul öncesi eğitimle ilgili yapılacak program ve uygulamaların çocuk merkezli olması gerekliliği kararı alınmıştır (Gülay \& Ekici, 2010, s. 75). Okul öncesi eğitimi yaygınlaştırma yönünde çalışmalar yapılmasına rağmen bu kurumlardan yararlanma oranının düşük olduğu gözlenmektedir. Türkiye'de 0 ile 6 yaş grubunu kapsayan okul öncesi eğitimden yararlanma oranı $\%$ 39'dur (Erkan \& Kırca, 2010, s. 95). Tam gün ya da yarım gün olarak uygulanabilen okul öncesi eğitimde özel kuruluşlara bağlı olanları ücretlidir. Milli Eğitim Temel Kanunu'na göre okul öncesi eğitimin amaçlanı şöyledir; "Çocukların beden, zihin ve duygu gelişmesini ve iyi alışkanlıklar kazanmasını sağlamak, Onları ilköğretime hazırlamak, Şartları elverişsiz çevrelerden ve ailelerden gelen çocuklar için ortak bir yetişme ortamı yaratmak ve Çocukların Türkçeyi doğru ve güzel konuşmalarını sağlamak” (Yıldırım, 2008, s. 93).

\section{1.İngiltere'de Çocuk Yoksulluğu ve Sosyal Yardımlar}

İngiltere'de çocuk yoksulluğu üzerine durulmakta ve bu durumun asgariye indirgenmesi için çeşitli devlet politikaları uygulanmaktadır. Çocuk yoksulluğuna dikkat çekmek için önce 
insanlardaki yoksulluk kavramı zihniyetinin değişmesine inanan İngiliz akademisyenler risk altında olan gruplar için çingeneler, mülteciler, evsizler, azınlıklar, gey ve lezbiyen grupları içerisindeki çocukları işaret etmektedirler (Fraser, 2009, s. 92). Yoksul (deprived) bölgelerde yapılan çalışmalarda öğretmenler öğrencinin öğrenme isteği konusunda olumsuz görüşler bildirmektedir. Öğrencilerin öğrenme yerine zaman geçirme amaçlı uygun olmayan davranışlarda bulunduklarını belirten öğretmenler, bu bölgelerde öğretmenin kolay olmadığını dile getirmektedir. Ekonomik açıdan daha iyi olan bölgelere göre yoksul olan öğrencilerin İngilizce, Matematik ve ortaokul sonunda girdikleri sinavlarda daha az başarılı oldukları gözlemlenmektedir. İngiliz hükümeti bu bölgelere en tecrübeli ve mesleğine kendini adamış öğretmenlerini göndermek istemektedir. 2011 y1lında aile öğrenimi için, bütçeden 37 milyon sterlin ayrılmış ve kamu bu ödeneğin dezavantajlı aileler için harcanmasını hedef olarak belirlemiștir. İngiltere kanunlarında (Eşitlikler Yasası-Equality Act gibi), eğitim verecek olan kurumların özellikleri açık bir şekilde belirtilmiş ve dezavantajlı grupların bu eğitim kurumlarından ayrımcılık söz konusu olmaksızın nasıl yararlanabileceklerinin altı çizilmiştir.* Çocuk yoksulluğu ile mücadele konusunda "Opportunities for All” (Herkes için firsatlar) sloganıyla hareket edilmektedir. 0-4 yaş arasındaki yoksul çocuklar desteklenmekte, "Sure Start" uygulamasıyla çocukların temel ihtiyaçları karşılanmaktadır (Avşar Kurnaz, 2009, s. 73). Nüfusun etnik, kültürel ve dini açılardan çeşitlilik arz ettiği İngiltere kentlerinde genel olarak bir refah seviyesi görülse de bazı yerleşim bölgelerinde çocuklar ve ailelerin ekonomik sıkıntılar ve sosyal yaşam alanında sorunlar yaşadıkları gözlenmektedir. İngiltere'de genel olarak kadın ve erkek nüfusu sayıca birbirine eşit olup, etnik ve dini yapı da çeşitlilik göstermektedir. (Taşçı, 2008, s. 220). Muhtaç bir çocuk ya da ailesi sosyal hizmetlerden durumunun değerlendirilmesini isteme hakkına sahiptir. Bu değerlendirme, gerekli servisleri belirler ve oldukça önemlidir, çünkü birden fazla hizmet ağıyla bağ kurması gerekebilir, örneğin; ev hizmeti ya da kısa dönemli dinlenmeler gibi. Belli bir bölgede özürlü çocuk sayısının fazla olmasıyla sosyal hizmetlerin maddi imkanları sınırlılık gösterebilir. Bu durumda belediye, "uygunluk kriterleri" ilkesi ile verilmesi gerekeni tespit eder. Uygunluk kriterleri her yerel merciye göre değişkenlik gösterebilir. Bunun anlamı, bir bölgeden başka bir bölgeye taşınma durumunda önceden sağlanan yardımlardan yoksun kalınabilir. Uygunluk ya da değerlendirme aşamasında eğer sosyal hizmetler aileyi ya da çocuğu yardım almaya muhtaç olarak görmezse, herhangi bir hizmeti sunmak zorunluluğu yoktur fakat, bu durumda bile ailenin yerel yardım dernekleri, vakıflar veya gönüllü kuruluşlarla irtibata geçmesi sağlanmaktadır. Ayrıca, ailenin verilen kararı daha ileri şikayet seviyesine taşıyabilmesi için, neden uygunluk kriterlerine uymadıkları açıkça belirtilmelidir. 1989 Çocuk Yasası'na göre, yerel merciler sundukları hizmetlerden para talep edebilirler ve her yerel belediyenin fiyatlaması farklı olabilir. Ödemeler ailenin gelirine ve yatırımlarına göre belirlenerek ailenin ödeyemeyeceği rakam talep edilemez. Çocuk 16 yaşına ulaştığında artık ailenin gelir durumu değil, çocuğun kendi şartları birey olarak ele alınır. Aile, devletten çalışma vergi kredisi, çocuk vergi kredisi ya da işsizlik kredisi gibi yardımlar alıyorsa çocuklara sunulan hizmetlerden ücret alınmaz. Ayrıca, tavsiye, bilgilendirme ve rehberlik servislerinden finansal durum ne olursa olsun ödeme alınmaz (Parkes, 2012, s. 9).

\subsection{1.Çocuk Bakım Üniteleri}

İngiltere'de okul öncesi çocuklara yönelik bakım ve eğitim merkezleri olarak; günlük bakım kreşleri (daycare), çocuk merkezleri (Children's Centres), oyun grupları, okullara bağlı okul öncesi birimler, tatil faaliyetleri, okul öncesi ve sonrası kulüpleri bulunmaktadır. Bu merkezlerde verilen hizmetlerde geniş ölçekte planlama ve etkinlik yapıldığ gibi, çocukların sağlık ve günlük bakım işlemleri de sağlanmaktadır (Şemşek, 2014, s. 209). Günlük Bakım Kreşleri (Daycare),

\footnotetext{
* Bkz. The UK Equality Act 2010, http://www.legislation.gov.uk/ukpga/2010/15/pdfs/ukpga_20100015_en.pdf, Erişim 11.5.2015.
} 
çocukları 3 aylıktan 5 yaşa kadar kabul etmektedirler. Genellikle, bebek odası ( $0-2$ yaş), 2-3 yaş arası ve 3-5 yaş arası gurupların sınıfları birbirinden ayrı tutulur. Çocuklar serbest oynama zamanında bir araya gelirler. Bu kreşlerde çocuğun günlük hijyen bakımlarının yanı sıra yeme, içme ve uyuma ihtiyaçları karşılanır. Öğrenimlerini pekiştirecek şekilde okula hazırlık uygulamaları yapılır. Fiziksel ve zihinsel engelli çocuklara özel 1 ya da 2 yardımcı öğretmen atanır. Öğretmenler gün içinde bu çocukların ihtiyaçlarını karşılamakla sorumludur (Guidance to the National Standards, 2010, s. 45). Çocuk Merkezleri (Children's Centres), 5 yaş altı çocuklara hizmet veren çocuk merkezleri, bünyesinde, oyun eğitimleri, konuşma terapistleri, sağlık merkezi ve anaokulu gibi farklı birimleri bulundurur. Ülkenin hemen hemen her ilçesinde bulunurlar. Hem çocuklar hem de aileleri için çeşitli eğitim programları sunarlar. Programlara örnek olarak; bebek masaj seansları, ebeveyn eğitimleri, davranış bozukluğuna karşı eğitim, doğum öncesi sağl1k hizmetleri, çocuklar ve aileleri için yoga hizmetleri verilebilir. Oyun Grupları (Play Groups), genellikle 3 yaş grubunun altına hizmet verir. Ana tema olarak serbest oyun oynamayı ele alırlar. Ebeveyn isterse çocuğu ile birlikte kalabilir. Engelli çocuğun ihtiyacına göre 1 ya da 2 öğretmen eşlik eder. 2 saatlik seanslar şeklinde ya bir kilise salonunda ya da kamuya ait bir binada hizmet verir. Hem içeri hem de dişarı alanlarda farklı oyun çeşitleri sunulur (Şemşek, 2014, s. 210). Okul Öncesi Birimleri (Nursery), 3-4 yaş arası çocuklar ilkokulların anaokulu bölümünden başlayıp daha sonra okula hazırlık (reception) sınıfı ve nihayetinde 1. sınıfa başlayarak ilkokulu 6. sinıfa kadar okurlar. Herhangi bir öğrenme engeli olan çocuklar için sağlık ve sosyal hizmetler personelleri ile birlikte çalışılır. Bu çalışmalar sırasında okul personeli diğer profesyonellere yardımcı olur. Bu profesyoneller, terapistler, göz ve kulak doktorları, psikologlar, sosyal hizmet görevlileri ve hemşireler olabilir. Çocukların engellilik derecelerine göre ortamın ergonomikliği, doğru teçhizatlar ve eşyalar ile sağlanır. Örnek olarak; rahat oturabilecekleri sıra ve sandalyeler, parmaklarına göre özel tutacaklı kalemler, yemek masaları, tekerlekli sandalyeler ve dinlenme mekanları verilebilir (Bruce \& Meggit, 2002, s. 182). Okul Öncesi ve Sonras1 Kulüpleri, okul başlama saatinden önce, özellikle çalışan aileler için çocuklarını erkenden bırakılabilecekleri kahvaltı grupları mevcuttur. Okul bünyesinde ya da özel binalarda organize edilebilirler. Çocukların kahvaltı ihtiyaçları karşılandıktan sonra oyun ve ders aktiviteleri yapılır. Okul sonrası gruplar1; "genelde okul bitiminden itibaren 2 saatlik seanslar şeklinde düzenlenir. Kahvaltı grupları gibi okula bağlı olabilir ya da özel bir kuruluş tarafindan yürütülebilir. Futbol, satranç, hokey, kriket, etüt, oyun ve dinlenme gruplart şeklinde organize edilebilirler. Kulüpler okul dışında bir binadaysa, okul bitiminde çocuklar, yürüme ya da servis yöntemiyle kulüp çalışanları tarafindan alınır. Bu merkezlerde engelli çocukların ihtiyaçları aile ve sağllk hizmetlerinin öngördügü̈ şekillerde karşılanır” (Şemşek, 2014, s. 211). Tatil Kulüpleri, Okul tatillerinde, yerel belediyeler ya da özel kurumlar tarafından genelde okul spor salonlarında yürütülürler. Etkinlikleri arasında spor, müzik, tiyatro, resim ve sanat gelir. Çocuklar eğitilmiş görevlilerle birlikte çalışırlar. Yaş gurubu genelde 4 yaş ile 12 yaş arasıdır. Bütçenin çoğu yerel belediye tarafından karşılansa bile aileler belli bir ücrete tabi tutulabilir. Bu hizmetler hemen hemen bütün bölgelerde okul tatil zamanlarında sunulur (Bruce \& Meggit, 2002, s. 183).

\subsubsection{Eğitimde Fırsat ve İmkân Eşitliği}

Yazılı kanunlarla kişilerin özgürlükleri korunmuş ve eşitlik ilkesinin yayılma sorumluluğu hem işverene hem de çalışana yüklenmiştir (Şemşek, 2014, s. 206). Eşitlik ilkesini ve insanların ayrımcılığa karşı korunmasını öngören başlıca yasalar şunlardır; Ruh Sağlığı Yasası (1983), Çocuk Hakları Sözleşmesi (1989), Temel Hak ve Özgürlüklere İlişkin Avrupa Sözleşmesi (1950), Engellilik ve Ayrımcılık Yasası (1995), İnsan Hakları Sözleşmesi (1998), Irk İlişkileri Yasası (2000), Çocuk Kanunu (2004) ve Kaliteli Bakım Komisyon Yönetmeliği (2009). 1989 Çocuk Hakları Yasası 17. bölümüne göre, sosyal hizmet birimleri engelli çocukları korumak ve ihtiyaçlarını ön plana çıkartmakla yükümlüdür. Yasa, engelli çocukları, ihtiyacı olan olarak 
tanımlamaktadır. Aynı bölüme göre; bir çocuk görmüyorsa, duymuyorsa, konuşamıyorsa, zekâ geriliği ya da herhangi bir zihinsel sorunu varsa ve hastalığı kalıcı ise engelli sayılmaktadır (Çocuk Hakları Sözleşmesi, 1989). Ayrıca İngiltere'deki Sosyal Hizmetler Birimi'nin engelli çocuklara ve ailelerine karşı görevleri şu şekilde sıralanabilir; Bir sosyal hizmet sağlama, Özürlü çocukların kaydını muhafaza etme, Mevcut servisler hakkında bilgi verme, Özürlü çocukların ve ailelerinin ihtiyaçlarını saptama, Bu ihtiyaçların karşılanması için gereken hizmet ağını oluşturma (Parkes, 2012, s. 3). Son 20 yıldır engelli insanlara karşı devlet yönetimlerinin ve uluslar arası örgütlerin bakış açısı değişmeye başlamış olup, özellikle $\mathrm{AB}$ ülkelerinde, herhangi bir engeli olmayan insanlardan ayırt edilmemişlerdir. Engelliler için yapılan uluslararası düzenlemelerin ülkeler çerçevesinde de uyumlaştırılması öngörülmüştür. İngiltere'de 2004 yılında özel eğitime ihtiyac1 olanlar için Special Educational Needs (SEN) derneği kurulmuştur. SEN, engelli çocukların kendi yeteneklerinin farkına varmalarını hedeflemektedir (Kilimci, 2006, s. 106). Yerel eğitim otoriteleri eğitim finansını sağlamaktadır (Kilimci, 2006, s. 73). Yerel mercilerin engelli çocuğu olan ailelere yardım etme sorumluluğu vardır. Bazı aileler özellikle ev ortamında günlük yaşamlarını idame ettirebilmek için daha çok yardıma ihtiyaç duymaktadırlar. Yerel belediyelerde düzen sağlamak amacıyla 2006 yılında "Çocuk Bakım Yasası" (The Childcare Act) kabul edilmiştir. Bu Yasa'ya göre belediyeler, okul öncesi yaş gruplarının eğitim alt yapılarını sağlamak, çocuk merkezlerini geliştirmek, dezavantajlı çocuklara ve ailelerine daha fazla hizmet sunmak, ailelerin tekrar işe dönme kararı almaları durumunda gerekli çocuk bakım ünitelerini devreye sokmak ve sosyal hizmet bölümlerinde uzman elemanlar bulundurmak gibi konularda sorumlu tutulmuşlardır. Yasalara göre İngiltere'de bulunan yerel merciler engelli çocuğu olan aileler için geniş çerçeveli bir yardım planı hazırlamakla yükümlüdürler. Bu plana göre;

- Engelli çocuğa evinde ya da başka bir bakım ünitesinde, gündüz ve gece bakımı sunulmasi ve,

- Veli için akşamları, hafta sonları ve okul tatillerinde destek hizmeti sağlanması zorunludur (Taşç1, 2008, s. 227).

1 Ekim 2011 tarihinden itibaren yerel merciler, aileler için sağlanacak olan hizmetleri, hizmetlerden kimlerin yararlanabileceği ve bu hizmetlerin onların ihtiyaçlarını sağlamada nasıl bir fayda göstereceğine dair gerekli bilgiyi yazılı hale getirmekle yükümlüdürler. 2014 yılından itibaren İngiltere'de bütün durum değerlendirme sistemleri aynı çatı altında toplanarak tek bir sistem haline getirilmiştir. Ayrıca Durum Değerlendirme Sistemi (Assessment Framework)'nin 25 yaşına kadar olan çocuk ve gençleri kapsayıcı nitelikte olması hedeflenmektedir (Parkes, 2012, s. 22).

\subsection{Finlandiya'da Çocuk Yoksulluğu ve Sosyal Yardımlar}

Finlandiya, Avrupa'da çocuk yoksulluğu oranının en düşük olduğu ülkelerden birisidir. Bunun nedeni olarak ülkede, çocuklar ve ailelerle ilgili güçlü devlet politikalarının bulunması gösterilebilir. Aileler için uygun düzeyde gelir sağlanmaktadır. Çalışmaya devam etmek isteyen ailelerin 7 yaş altındaki çocukları için gündüz bakım evleri sağlanmıştır ve eğer çalışmayıp çocuğunu yetiştirmek isteyenler olursa işlerini kaybetmeden bu olanaktan da yararlanabilmektedirler (European Agency, 2015). Aileler, çocukları 18 yaşına gelene kadar onların bakım ve yetiştirilmesinden sorumludur. 17 yaşın altındaki her çocuk için ödenek verilmektedir. 2014 verilerine göre aylık tek çocuk için ödenen rakam 104,19 Euro'dur. Ayrıca eğer tek ebeveyn söz konusu ise ek olarak 48,55 Euro ödenmektedir. Çocuk doğumlarında annelik ve babalık izinleri verilmektedir. Annelik izni 18 hafta, babalık izni 9 hafta, ebeveyn izni olarak da 26 hafta verilmektedir, böylece çocuğun ilk 1 yılı ailesinin yanında geçirmesi sağlanmaktadır. İzinlerde aileye; ebeveyn gelirinin \% 70-90 arasında bir ödenek sağlanmaktadır. Ayrıca işsiz olan veliler için de aynı yardım söz konusudur. Eğer veli bir yılın sonunda işe 
dönmek istemiyorsa çocuk üç yaşına gelene kadar aile desteklenmekte ve veli işine dilerse üçüncü yılın sonunda tekrar devam edebilmektedir. Ayrıca çalışan veliler, çocukları ilkokul ikinci sınıfın sonuna gelene kadar çalışma saatlerini azaltabilirler. Ücretsiz olan sağlık bakım hizmetlerinde, çocuk okul yaşına gelene kadar devamlı sağlık kontrolleri yapılır. Çocuk okula başladıktan sonra okul sağlık planı çerçevesinde sağlık kontrolleri devam eder (European Agency 2015). Konut yardımı konusunda farklı çeşitlilikte yardım yapılmaktadır. Hane gelirine göre genel konut yardımı, devlet garantili ev kredisi ve alınacak kredilerde vergi indirimi gibi uygulamalar söz konusudur (Finlandiya Aile ve Çocuk Politikası, 2013).

\subsection{1.Çocuk Bakım Üniteleri}

Finlandiya'da aileler için birden fazla çocuk bakım ünitesi mevcuttur. Kadınların iş hayatında etkin bir şekilde yer almasıyla yasalarda okul öncesi yaş grubu için düzenlemeler yapılmıştır. Çocuğun doğumu için alınan ebeveyn izninden sonra ailenin çocuğunu bırakabileceği kurumlara yönelik devlet destekli üç seçenek sunulmuştur; 1- Belediye gündüz bakım evleri: $\mathrm{Bu}$ merkezler bir binada ya da aile gündüz bakım evi de olabilir, 2- Özel gündüz bakım evleri: $\mathrm{Bu}$ merkezler bir binada ya da aile işletmesi şeklinde olabilir ve ödemeler devlet tarafindan desteklidir, 3- Evde bakım: Velilerden biri çocuk 3 yaşın altındaysa "Çocuk Ev Bakım Ödeneğii" alarak kendi evinde bakım seçeneğini seçebilir. Okul öncesi kurumlarının işleyişinden ve kalitesinden yerel yönetimler sorumludur. Aile bir işyerinde çalışıyor olsun ya da olmasın çocuğunu bu merkezlere yerleştirme hakkına sahiptir. Finlandiya'da gündüz bakım sistemi 'EduCare' modeliyle hem bakım, hem yetiştirme hem de eğitim hizmeti verir. Okul öncesi kurumlar "Ulusal Okul Öncesi Eğitim ve Bakım Stratejisi (ECEC)" ne dayanır. Yerel otoriteler çocuğun anadilinde eğitim vermekle yükümlüdürler ve bu diller Fince, İsveççe ve Saami olarak belirlenmiştir. $\mathrm{Bu}$ hizmetlerin yanı sıra, oyun alanlarında, kiliselerde ve sivil toplum kuruluşlarının (STK) belirlediği yerlerde çocuk bakım hizmetleri sunulmaktadır. Gelir düzeyi iyi olmayan ailenin çocuğu için bakım ücreti alınmamaktadır. Öğretim, Ulusal Okul Öncesi Müfredatı'ndan türetilen yerel müfredatla yapılmaktadır (Finlandiya Aile ve Çocuk Politikası, 2013).

\subsubsection{Eğitimde Fırsat ve İmkân Eşitliği}

Finlandiya'da eğitim hizmeti bireylerin yaş, engellilik, ekonomik durumları gibi farklılıklarına bakılmaksızın sunulmaktadır. Diğer eğitim basamakları gibi okul öncesi eğitimin giderleri de devlet tarafindan karşılanabilmektedir. Yerel yönetimler tarafından sunulan hizmetler arasında; okula ulaşım, yemek ve okul ders araç ve gereçleri gibi hizmetler vardır. "Herkes için ve her yerde eğitim" sloganıyla hareket eden Finlandiya, eğitimi çok yönlü boyutlarda şekillendirmiştir. Fince'nin yanı sıra diğer dillerde de eğitim veren okul öncesi kurumları bulunmaktadır (Genellikle İsveççe veya İngilizce). Eğitim standartları her bölgede aynı seviyede seyretmektedir. "Azınlıklar, Roman toplumu ve dezavantajlı bütün birey veya gruplara birtakım pozitif ayrımcılıklar sağlanarak eğitim olanaklarından istifade etmeleri săglanmaktadır”" (Ekinci \& Öter, 2010, s. 11). Okul öncesi eğitimde, kurumlar velilerle işbirliği içerisinde çalışmaktalar ve çocukların ihtiyaçları alınan ortak kararlarla belirlenmektedir. Engelli çocukların, diğer öğrencilerle aynı eğitim ve öğretim imkanlarına sahip olmaları gerektiği Finlandiya Anayasası'nda açıkça belirtilmiş ve kanunen güvence altına alınmıştır. Engelli çocukların eğitiminde özel eğitim alanında eğitim almış öğretmenler görevlendirilmektedir. Her özel eğitimden yararlanan çocuk için Bireysel Öğretim Planı (IEP) çıkarılması zorunludur. Engeli olan öğrenciye mesleki eğitim ve öğretim sunulduğu gibi okul öncesi eğitim olanağ 1 da sunulmaktadır (Ekinci \& Öter, 2010, s. 18). Okul öncesi yaş grubunda engelli çocukların eğitimi, ihtiyaçları ve hakları Finlandiya Anayasası'nın yanı sıra uluslararası bildirilerle kanunlar çerçevesinde, insan haklarına ve küresel uygulamalara paralel olarak düzenlenmiştir. Eğitim ortamı fiziksel ve sosyal 
koşullara uygun bir şekilde engeli olan öğrencinin yararlanabileceği düzeyde oluşturulmaktadır. Zorunlu eğitim yaşına gelen çocuklar özel eğitim veren merkezlerden daha fazla istifade edebilmektedirler. Ulusal müfredatda özel eğitim alacak olan okul öncesi çocukları için verilecek destek, üç gruba ayrılmıştır; 1- Genel destek, 2- Yoğun destek, 3- Özel destek. Bu destekler süresince görevlendirilen "Öğrenci Refahı Ekibi” tarafından özel eğitim alacak olan çocuğun pedagojik denetimi yapılır. Bu denetimden sonra varılan sonuçlara göre Bireysel Eğitim Planı (Individual Education Plan-IEP) hazırlanır (European Agency, 2015).

\subsubsection{Bireysel Eğitim Planı (Individual education plan)}

Özel eğitim alacak olan çocuğa doğru desteğin verilebilmesi için Bireysel Eğitim Planı (IEP) hazırlanmaktadır. Plan'da öğrencinin nasıl bir eğitim alması gerektiğine ve diğer desteklere yer verilmektedir. IEP; yazılı, pedagojik ve müfredata dayalı bir belgedir. Bu Plan'ın hazırlanmasındaki amaç öğrencinin kalıcı ve sürekli bir destekten yararlanmasını sağlamaktır. Ayrıca öğrencinin öğrenimi, okula katılımı ve eğitim basamakları pedagojik metodlarla ve gerekli diğer desteklerledüzenlenmektedir. IEP'te yukarıdakilerin haricinde belirtilmesi gerekenler; öğrencinin hangi derslerde destek alacağı, hedeflenen nokta, gözlem ve denetlemenin gidişatı, öğrenciye öğrenimini sergilemesi için verilen imkanlar, denetimin yöntemi ve zamanıdır. Yapılan planın gereken sıklıkta gözden geçirilmesi ve yılda en az bir kere bu uygulamanın yapılması zorunludur (European Agency, 2015).

\subsection{Türkiye'de Çocuk Yoksulluğu ve Sosyal Yardımlar}

Türkiye'de çocuk yoksulluğu incelendiğinde ve Türkiye İstatistik Kurumu (TÜíK) verilerine bakıldığında çocuk yoksulluğunun yetişkin yoksulluğundan daha fazla olduğu görülmektedir. Ayrıca sokak çocukları ve çocuk işçiler konuları da sık sık gündeme gelmektedir. 1999'da yapılan bir çalışmaya göre 6-17 yaş arasında çocukların \% 57,6'sının tarım, \% 21,8'inin sanayi, $\%$ 20,6'sının hizmet alanında çalıştığ tespit edilmiştir. Okul öncesi eğitimin çocuk yoksulluğunun engellenmesi ve bireysel gelişimi sağlaması konusundaki önemi dünya çapında kabul edilmiştir. 2004 Dünya Bankası istatistikleri Türkiye'de okul öncesine katılımın \% 15 olduğunu göstermiştir. Diğer Avrupa ülkeleriyle karşılaştırıldığında bu oran düşük kalmaktadır. $\mathrm{Bu}$ durum okul öncesi eğitimin ailelere ekonomik yük getirdiği gerekçesiyle açılanabilir (Avşar Kurnaz, 2009, s. 64). Türkiye'de çocuk yoksulluğunu azaltmaya yönelik; Milli Eğitim Bakanlığı, Aile ve Sosyal Politikalar Bakanlığı ve Çalışma ve Sosyal Güvenlik Bakanlığı tarafından programlar ve projeler yürütülmektedir. Bu çalışmalara; Sosyal Yardımlaşma ve Dayanışmayı Teşvik Fonu, Şartlı Nakit Transferi, Koruyucu Aile Hizmeti, sokak çocukları için sunulan yatılı rehabilitasyon merkezleri uygulamalarını örnek olarak verebiliriz. Ayrıca Çalışma ve Sosyal Güvenlik Bakanlığı, çocuk işçiliğini önleme konusunda Uluslararası Çalışma Örgütü (ILO) ile, Milli Eğitim Bakanlığı ise kız çocuklarının okula devamlılığı konusunda UNICEF'le birlikte proje çalışmaları yapmaktadır (Avşar Kurnaz, 2009, s. 83). Aile ve Sosyal Politikalar Bakanlığı'na bağlı Sosyal Yardımlar Genel Müdürlüğü'nün en önemli görevlerinden birisi, "Mevzuatta kamu kaynaklarıyla yardım yapılması öngörülen kişilere aylık, tazminat, ücret ve yardım gibi her türlü sosyal yardımın ödenmesi için diğer kamu ve kuruluşlarla işbirliği dahilinde yerine getirmesidir" (Aile ve Sosyal Politikalar Bakanlığı, 2011). Aile ve Politikalar Bakanlığı tarafından düşük gelirli ailelere kaynakların yeterliliği ölçüsünde ayni ve nakdi destek yapılmaktadır. Çocuk Hizmetleri Genel Müdürlüğü tarafından gerçekleştirilen yardımlarla, öncelikle korunmaya muhtaç çocukların ekonomik yoksunluk çekmemeleri ve ailenin parçalanmadan bir arada tutulması hedeflenmiştir. "Sosyal ve ekonomik destek hizmetlerinde esas ilke, kişilerin kendi kendilerine yeterli duruma getirilmesidir" Y1lda iki kez Ramazan'da ve Kurban Bayramı öncesinde ihtiyaç sahibi ailelere gıda, giyim ve hane başına yılda $500 \mathrm{~kg}$ 'lık yakacak yardımı yapılmaktadır. Evleri oturulamayacak derecede eski, bakımsız ve sağlıssı olan 
ailelere bakım ve onarım için ayni ve nakdi yardım hizmet sunulmaktadır. Sağlık yardımı kapsamında 2012 yılı itibariyle bütün bireylerin sağlık hizmetleri Genel Sağlık Sigortası kapsamına alınmıştır. Nüfusun yoksul kesimlerinde 0-6 yaş arasında çocuğu olan ailelere aylık 30 TL yardım yapılmaktadır. Bu yardım doğrudan anneler adına açılan banka hesaplarına Ziraat Bankası ve PTT aracılığıyla ödenmektedir (Aile ve Sosyal Politikalar Bakanlı̆̆ı, 2014).

\subsection{1.Çocuk Bakım Üniteleri}

Türkiye'de okul öncesi eğitim veren kurumlar, Milli Eğitim Bakanlığı'na ve Aile ve Sosyal Politikalar Bakanlığı'na bağlı olanlar olmak üzere ikiye ayrılmaktadır. Milli Eğitim Bakanlı̆̆ı'na bağlı okul öncesi eğitim kurumları: Bağımsız anaokulları, İlköğretim bünyesindeki anasınıfları, Kız meslek liseleri bünyesindeki uygulama anaokulları ve anasınıfları, Aile ve Sosyal Politikalar Bakanlığı'na bağlı okul öncesi eğitim kurumları: Çocuk yuvaları, Çocuk bakımevleri, Çocuk kulüpleri ve Çocuk evleridir. Bunların yanı sıra ayrıca üniversitelerin bünyelerinde de okul öncesi eğitim kurumları bulunabilmektedir. Türkiye'de yaz okullarında ve mobil anaokullarında da okulöncesi eğitim verilmektedir. Yaz aylarında okul öncesi eğitimi yaygınlaştırmak ve geliştirmek, çalışan anne-babanın isteklerini karşılamak amacıyla okul öncesi eğitim veren yaz okulları bulunmaktadır. Mobil anaokulları ise; okulöncesi eğitimi yaygınlaştırmakve geliştirmek amacıyla, maddi imkânları yetersiz ailelerin çocukları için kuruma dayalı bir eğitim seçeneğiolarak uygulanır (Cevat, 2008, s. 93).

\subsubsection{Eğitimde Fırsat ve İmkân eşitliği}

Türkiye'de okul öncesi eğitim düşük gelirli aileler için yararlanma imkânı az olan bir kurumdur. Devlet tarafindan bazı ihtiyaçlar sağlansa bile okul öncesi eğitim, aile için ek bir masraf getirecek durumdadır. Bölgeler arası çocukların eğitimi konusunda eşitsizlikler mevcuttur. Türkiye'nin doğusunda, batısına kıyasla okullaşma oranı daha düşüktür. Bazı bölgelerde okula ulaşma sorunu vardır. Eğitimde fırsat ve imkân eşitliğinin önündeki en büyük engel ekonomik koşullardır. Türkiye'de özel eğitime ihtiyacı olanlar için kaynaştırma sınıfları ve özel eğitim okulları mevcuttur (Kilimci, 2006, s. 78). Uygulanan özel eğitimlerde bireylerin eğitim ihtiyaçları en iyi şekilde karşılanarak, toplumla bütünleşmeleri hedeflenmektedir. Özel eğitim kurumlarında; görme, işitme, ortopedik, zihinsel engelli eğitiminin yanısıra, süreğen hastalığ 1 olanların, otistik çocukların, üstün veya özel yeteneklilerin eğitimi de verilmektedir. Okul öncesi yaş gruplarında özel eğitime ihtiyacı olan çocukların öncelikle velileri bilinçlendirilmektedir. Bu doğrultuda üniversitelerle iş birliği yapılarak, tanıma, izleme ve değerlendirme ekibi desteğiyle eğitim, özel eğitim öğretmeni tarafından evlerde ve kurumlarda verilir. Ekip tarafından yapılan inceleme ve değerlendirme çalışmaları en az altı ayda bir yinelenir. Yapılan çalışmalarda aile ve çocuğun ihtiyaçları belirlenir ve ne tür hizmetlerin gerektiği kaydedilir. İhtiyaçlar arasında çocuğun sosyal yönden gelişimi ve ailenin desteklenmesi için çocuğun bir kreş, oyun grubu ya da etkinlik kurumuna katılması kararı verilebilir (Çetinkaya, 2005, s. 29).

\section{Sonuç}

Örnek ülkelerde okul öncesi eğitim yapı bakımından benzerlik göstermektedir ve zorunlu bir eğitim süreci değildir. Türkiye'de bu iki ülkeye nazaran okul öncesi okullaşma oranı daha düşüktür. Özellikle kırsal bölgelerde gerek okul yetersizliği, gerekse ailelerin olanaklarının elverişli olmayışı okul öncesi eğitimden yararlanılamadığını göstermektedir. Özel ve devlet okullarına bağlı okul öncesi kurumlarının olanakları değişkenlik göstermektedir. $\mathrm{Bu}$ durum Finlandiya ve İngiltere okullarında gözlenmemiştir. Örnek ülkelerin sosyo-ekonomik yapıları farklıdır. Nüfusun etnik ve dini yapısı çeşitlilik göstermektedir. Okul öncesi eğitim özellikle İngiltere hükümet gündemlerinin üst sıralarında yer almaktadır. Söylemler her üç devlet hükümetlerinde benzerlik göstermekte, zorunlu eğitime hazırlık aşamasında çeşitliliğin, yeniliğin, esnekliğin ve eğitimde seçim hakkının önemi sürekli vurgulanmaktadır. 
Öğretmen yetiştirme konusunda özellikle Finlandiya'nın öğretmenlerini yüksek lisans mezunu olanlar arasından seçmesi dikkat çekicidir. Türkiye'de öğretmen ve öğrenci yetiştirilmesi konusunda diğer ülkelerle aynı amaçlar doğrultusunda hareket edildiği ve özellikle Türkçe'nin doğru ve etkin bir şekilde kullanılması gerektiği ön plana çıkmaktadır. Öğrenciyi yönlendirme konusunda okul-veli işbirliği, İngiltere ve Finlandiya'da Türkiye'ye oranla daha etkin olduğu gözlenmiştir. Finlandiya eğitim-öğretim müfredatının, İngiltere ve Türkiye'ye göre daha esnek ve yerel olduğu, İngiltere ve Türkiye'de ise daha sabit ve merkezi olduğu sonucuna varılmıştır. Üç ülkede de zorunlu eğitime başlama yaşı farklıdır.

İngiltere, Finlandiya ve Türkiye'nin eğitim finansman sisteminde eğitim için ayrılan pay ülkelerin gelişmişliklerine göre farkl1lık göstermektedir. Finansman yöntemleri farklı kategorilerde değerlendirilmektedir. Türkiye'de merkezi kaynağa ağırlık verilmekteyken, İngiltere ve Finlandiya'da yerel kaynaklar ağırlıktadır. Velilerin çalışma saatlerini azaltabilme, çocukların okul öncesi bakım hizmetlerinden ücretsiz olarak yararlanabilmeleri uygulamaları konusunda Finlandiya örneği incelenebilir. Türkiye'de Aile ve Sosyal Politikalar Bakanlığı'nın eğitim araç-gereç yardımı, şartlı eğitim yardımı, öğle yemeği yardımı ve ücretsiz kitap yardımı gibi eğitim hizmetlerinden okul öncesi yaş grubu yararlanamamaktadır. Okul öncesi eğitimden yüksek gelire sahip ailelerin yararlanma oranı daha yüksektir. Yoksulluk sınırı altında olanların örgün ve yaygın eğitime erişirliliği sağlanmalı ve gerekli denetimler yapılmalıdır. Eğitimin, toplumsal eşitsizliği düzenleyici etkisinden yararlanılarak özellikle imkân ve fursat eşitliği konusunda gerekli eğitim politikaları üzerinde çalışılmalıdır. Yapılan çalışmada, okul öncesi yaş grubuna yönelik sunulan hizmet ve politikaların sadece çocuk ile ilişkin olmadığı, doğrudan veya dolaylı olarak çocuğun ailesini de kapsadığı sonucuna varılmıştır. Dolayısıyla bu durum ailenin sosyo-ekonomik seviyesinde olumlu sonuçlar yaratmakta, çalışma hayatına dönmek isteyen anne ya da baba için firsat teşkil etmektedir. Okul öncesine yönelik uygulanan sosyal politikaların ve hizmetlerin istihdam seviyesinde olumlu etkisi olduğu gibi ebeveynlere çocuklarını yetiştirme görevlerinde yardım mekanizması oluşturarak kendilerine daha fazla zaman ayırmalarını sağlamaktadır.

\section{Kaynakça}

Aile ve Sosyal Politikalar Bakanlığı. (2011). Kanun Hükmünde Kararname. Erişim Adresi: http://www.aile.gov.tr/

Aile ve Sosyal Politikalar Bakanlığı. (2014). Şartlı Sağlık Yardımı. Erişim Adresi: http://www.aile.gov.tr/

Akbıyık, C. ve Kalkan Ay, G. (2014). Okul Öncesi Yönetici ve Öğretmenlerin Düşünme Becerilerinin Öğretimine Yönelik Algıları: Bir Durum Çalışması. Hacettepe Üniversitesi Eğitim Fakültesi Dergisi, 29 (1), 01-18.

Atılgan, G. ve Çakar B, Y. (2007). Yoksulluk ve Sosyal Dışlanma, Tes-İş Dergisi, 68-106. Erişim Adresi: http://www.tes-is.org.tr/TR/tesis_dergi/2007_haziran/pdf/dosya.pdf

Ayrangöl, Z. ve Tekdere, M. (2014, Aralık). Türkiye ve OECD Ülkelerinde Yapılan Eğitim Harcamalarının Karşılaştırmalı Analizi. EUL Journal of Social Sciences (V:II) LAÜ Sosyal Bilimler Dergisi.

Balseven, H. (2009). İngiltere'de Refah Reformlarının Ekonomi Politiği. Sosyal İnsan Haklanı Sempozyum Bildirisi, 337-349. Erişim Adresi: 
http://www.sosyalhaklar.net/2009/bildiri/balseven.pdf

Bruce, T. ve Meggit, C. (2002). Child Care and Education. Oxon, Stoughton: Hodder.

Children's Workforce Development Council. (2009, Plymouth). The Common Assessment Framework for Children and Young People. Erişim Adresi: http://www.plymouth.gov.uk/caf_for_practitioners_national_guidance.pdf

Çalışkan, Ş. (2007). Eğitim-İ̧sizlik ve Yoksulluk İlişkisi. Selçuk Üniversitesi İİBF Sosyal ve Ekonomik Araştırmalar Dergisi, 285-308.

Çetinkaya, M. Ö. (2014). Ortaöğretim Coğrafya Programları Açısından Finlandiya ve Türkiye’nin Karşılaştırılması (Yüksek Lisans Tezi, Ankara). Gazi Üniversitesi, E.B.E.

Çetinkaya, Ş. (2005). İnsan Sermayesi Açısından Avrupa Birliği’nin Eğitim Politikası ve Avrupa Birliği Ülkelerindeki Eğitimin Finansal Yapısının Türkiye ile Karşılaştırılması (Yüksek Lisans Tezi, Konya). Selçuk Üniversitesi, S.B.E.

Çınar, İ. (2009). Küreselleşme, Eğitim ve Gelecek. Kuramsal Eğitimbilim Dergisi, 2(1), 14-30.

Çiçekçisoy, Y. (2013). Yükseköğretimi finanse etme yöntemleri. Eğitim Portalı. Erişim Adresi: http://www.egitimtercihi.com/yazar/yasemin-cicekcisoy/11557-yuksekogretimi-finanseetme-yontemleri.html

Çocuk ve Gelişim. (2008). Okul Öncesi Eğitim ve Önemi. Erişim Adresi: http://cocukvegelisimi.blogcu.com/okul-oncesi-egitim-ve-onemi/3556698

Department for Education. (2014). Engelli Eğitimi İstatistikleri. Erişim Adresi: https://www.gov.uk/government/statistics/special-educational-needs-in-england-january2014.

Department for Education. (2014), Çocuk Bakımı Ve Okul Öncesi Eğitim Sağlayanlar Anket Çalışması 2013, Erişim Adresi: https://www.gov.uk/government/uploads/system/uploads/attachment_data/file/355075/SFR3 32014 Main report.pdf

Department for Education. (2014), Statistics, Schools, education and children's services spending: 2013 to 2014. Erişim Adresi: https://www.gov.uk/government/statistics/schoolseducation-and-childrens-services-spending-2013-to-2014

Department for Education. (2001). Guidance to the National Standards: Sessional Day Care. DFES: Nottingham.

Doğan, C. (2003). AB'de Sosyal Politikalar ve İş Gücü Piyasasına Yönelik Etkileri (Doktora Tezi, Eskişehir). Anadolu Üniversitesi, S.B.E.

Ekinci, A. ve Öter, Ö. M. (2010, Kasım). Finlandiya'da Eğitim ve Öğretmen Yetiştirme Sistemi. Çalışma Ziyareti Raporu. Erişim Adresi:

http://duabpo.dicle.edu.tr/oygem/dosya/Finlandiya Raporu.pdf

Erkan, S. ve Kırca, A. (2010). Okul Öncesi Eğitimin İlköğretim Birinci Sınıf Öğrencilerinin Okula Hazır Bulunuşluklarına Etkisinin İncelenmesi. Hacettepe Üniversitesi Eğitim Fakültesi Dergisi, 38, 94-106. 
European Agency. (2015). Finland: Universal services and financial benefits to promote the wellbeing of all children and families. European Platform for Investing in Children. Erişim Adresi: http://europa.eu/epic/countries/finland/index_en.htm

Finlandiya Çocuk ve Aile Politikası. (2013, Helsinki). Finlandiya Sosyal İşler ve Sağlık Bakanlığı. Erişim Adresi: http://www.stm.fi/c/document_library/get_file? folderId=6511570\&name=DLFE-25916.pdf

Finlandiya Anayasas1. (1999). The Constitution of Finland 11 Haziran 1999. Erişim Adresi: http://www.finlex.fi/en/laki/kaannokset/1999/en19990731.pdf

Fraser, D. (2009), A Good Childhood. Hampshire: Palgrave Macmillan.

Gülay, H. ve Ekici, G. (2010, Mart). Okul Öncesi Eğitim Programının Çevre Eğitimi Açısından Analizi. Türk Fen Eğitimi Dergisi. yıl: 7, sayı: 1, 74-84, Erişim Adresi: http://www.tused.org/internet/tused/archive/v7/i1/text/tusedv7i1s7.pdf

Güngör, G. ve Göksu, A. (2013, Manisa). Türkiye'de Eğitimin Finansmanı ve Ülkelerarası Bir Karşılaştırma, Celal Bayar Üniversitesi, İ.İ.B.F.. Yönetim ve Ekonomi, cilt: 20, sayı: 1, 5972.

Heinamaki, L. (2008). Early Childhood Education in Finland. Berlin: Liberal Institute.

İngiltere İnternet Devlet Sayfası. (2014). When You Can Leave School. Erişim Adresi: https://www.gov.uk/know-when-you-can-leave-school

İngiltere Eğitim Bakanlığı. (2013). Childcare. Erişim Adresi:

https://www.gov.uk/government/uploads/system/uploads/attachment data/file/219660/More 20G reat_20Childcare_20v2.pdf

Kilimci, S. (2006). Almanya, Fransa, İngiltere ve Türkiye'de Sınıf Öğretmeni Yetiştirme Programlarının Karşılaştırılması (Doktora Tezi, Ankara). Çukurova Üniversitesi, S.B.E.

Kurnaz, Ş. A. (2009). Türkiye'de Çocuk Yoksulluğu (Sosyal Yardım Uzmanlık Tezi, Ankara). T.C Başbakanlık Sosyal Yardmlaşma ve Dayanışma Genel Müdürlüğü.

Milli Eğitim Bakanlığı. (2015, Ankara). Milli Eğitim İstatistikleri 2014/15. Erişim Adresi: http://sgb.meb.gov.tr/www/mill-egitim-istatistikleri-orgun-egitim-2014-2015/icerik/153

Mooney, C. G. (2000). Theories of Childhood. Minnesota: Redleaf Press.

Official Statistics of Finland. (2015, Helsinki). Special education. Erişim Adresi: http://www.stat.fi/til/erop/tup en.html

OECD. (2013). Eğitim Politikası Genel Görünümü: Türkiye. Erişim Adresi: http://abdigm.meb.gov.tr/meb iys dosyalar/2013 11/15024414 eitimpolitikasgenelgrnmtrki ye.pdf

OECD Indicators. (2013). Education at a Glance, Country Note. Erişim Adresi: http://www.oecd.org/edu/Finland EAG2013\%20Country\%20Note.pdf

Özdemir, S. (2007). Küreselleşme Sürecinde Refah Devleti. İstanbul: İTO. 
Parkes, J. (2012). Disabled Children's Services in England, Information for Families, Erişim Adresi:http://www.cafamily.org.uk/media/379444/disabled_childrens_services_currentlastup dated_oct_2012_low_res_web.pdf

Süngü, H. (2005). Fransa, İngiltere ve Almanya Eğitim Denetimi Sistemlerinin Yapı ve İşleyişi. Milli Eğitim Üç Aylık Eğitim ve Sosyal Bilimler Dergisi, yıl: 33,sayı: 167. Erişim Adresi: http://dhgm.meb.gov.tr/yayimlar/dergiler/Milli_Egitim_Dergisi/167/index3-sungu.htm

Şemşek, İ. (2014). Engelli Çocuklara ve Ailelerine Sağlanan Sosyal Hizmetler; İngiltere Örneği. Dezavantajlı Gruplar Eğitim ve İstihdam Sempozyum Bildirisi. Kocaeli Üniversitesi, 197212.

Şenkal, A. ve Sarıipek, D. B. (2007). Avrupa Birliği'nin Karşılaştırmalı Refah Modelleri ve Sosyal Politikada Devletin Değişen Rolü. Kocaeli Üniversitesi S.B.E. Dergisi, 14: 2, 146 175.

Taşçı, F. (2008). Yerel Yönetimlerde Sosyal Politika ve Sosyal Hizmetler: Londra Barnet Belediyesi Örneği. İstanbul Üniversitesi. 218-251.

Taştan, O. C. (2007). Neoliberal Stratejide Sosyal Politikanın Konumu: Türkiye Örneği (Yüksek Lisans Tezi). Ankara Üniversitesi, S.B.E.

Tokol, A. ve Alper, Y. (2013). Sosyal Politika. Bursa: Dora.

Trading Economics. (t.y). United Kingdom, Erişim Adresi: http://www.tradingeconomics.com/united-kingdom/gdp-per-capita

Türkiye Cumhuriyeti Anayasas1. (1982). Erişim Adresi:

http://www.mevzuat.gov.tr/Metin.Aspx?MevzuatKod=1.5.2709\&MevzuatIliski=0\&sourceXmlSe $\underline{\operatorname{arch}}$

Usta, H. G. (2014). PISA 2003 ve PISA 2012 Matematik Okuryazarlığı Üzerine Uluslararas1 Bir Karşılaştırma: Türkiye ve Finlandiya (Doktora Tezi). Ankara Üniversitesi, E.B.E.

Yıldırım, M. C. (2008). Avrupa Birliği Ülkelerinde ve Türkiye'de Okul Öncesi Eğitim. Elektronik Sosyal Bilimler Dergisi, c: 7, s: 25, 91-110. Erişim Adresi: http://dergipark.ulakbim.gov.tr/esosder/article/viewFile/5000068172/5000063236 